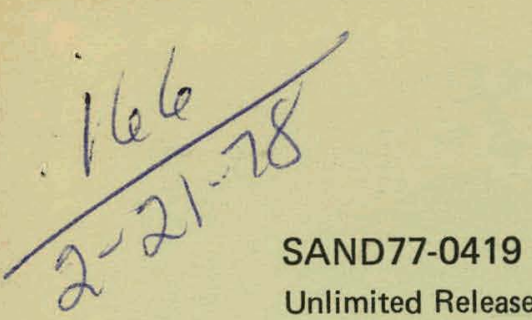

\title{
A Crash Test of a Nuclear Spent Fuel Cask and Truck Transport System
}

\section{MASTER}

Michael Huerta, Richard H. Yoshimura

Prepared by Sandia Laboratories, Albuquerque, New Mexico 87115

and Livermore, California 94550 for the United States Department

of Energy under Contract AT(29-1)-789

Printed January 1978

\section{Sandia Laboratories}




\section{DISCLAIMER}

This report was prepared as an account of work sponsored by an agency of the United States Government. Neither the United States Government nor any agency Thereof, nor any of their employees, makes any warranty, express or implied, or assumes any legal liability or responsibility for the accuracy, completeness, or usefulness of any information, apparatus, product, or process disclosed, or represents that its use would not infringe privately owned rights. Reference herein to any specific commercial product, process, or service by trade name, trademark, manufacturer, or otherwise does not necessarily constitute or imply its endorsement, recommendation, or favoring by the United States Government or any agency thereof. The views and opinions of authors expressed herein do not necessarily state or reflect those of the United States Government or any agency thereof. 


\section{DISCLAIMER}

Portions of this document may be illegible in electronic image products. Images are produced from the best available original document. 
Issued by Sandia Laboratories, operated for the United States Department of Energy by Sandia Corporation.

\section{NOTICE}

This report was prepared as an account of work sponsored by the United States Government. Neither the United States nor the United States Department of Energy, nor any of their employees, nor any of their contractors, subcontractors, or their employees, makes any warranty, express or implied, or assumes any legal liability or responsibility for the accuracy, completeness or usefulness of any information, apparatus, product or process disclosed, or represents that its use would not infringe privately owned rights.

Printed in the United States of America

Available from

National Technical Infurmatiun Service

U. S. Department of Commerce

5285 Port Royal Road

Springfield, VA 22161

Price: Printed Copy $\$ 4.00$; Microfiche $\$ 3.00$ 


\section{PAGES 1 to 2 WERE INTENTIONALLY LEFT BLANK}


SAND77-0419

Unlimited Release

Printed January 1978

\title{
A CRASH TEST OF A NUCLEAR SPENT FUEL CASK AND TRUCK TRANSPORT SYSTEM
}

\author{
Michael Huerta \\ Applied Mechanics Division II, 1282 \\ Richard $\mathrm{H}$. Yoshimura \\ Transportation Safety Technology Division, 5433 \\ Sandia Laboratories \\ Albuquerque, New Mexico 87115
}

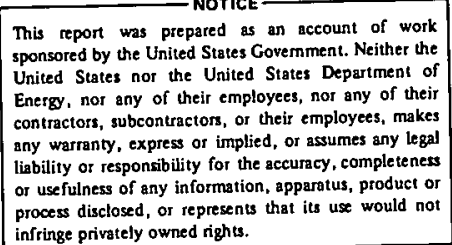

ABSTRACT

Sandia Laboratories has conducted a $96 \mathrm{kph}(60 \mathrm{mph})$ full scale truck impact test for ERDA's Environmental Control Technology Division. Rockets propelled a 20,500-kg (22-ton) cask mounted on its shipping trailer, coupled to a conventional rah-over tractor, into a massive, heavily reinforced concrete targel. This summary report describes and compares the results of the computer analysis, scale model, and full scale tests.

\footnotetext{
This work was supported by the United States Energy Research and Development Administration.
} 
Introduction

Page

Analysis

Scale Model Test

Full Scale Test

10

Comparison of Analysis to Full Scale Results

Conclusions

References 


\section{A CRASH TEST OF A NUCLEAR SPENT FUEL CASK \\ AND TRUCK TRANSPORT SYSTEM}

Introduction

Sandia Laboratories is conducting a series of full scale impact tests involving nuclear spent fuel "transport systems" for the Environmental Control Technology Division of the United States Energy Research and Development Administration (ERDA). A transport system consists of a shipping cask with its associated tiedown hardware and the vehicle on which it is transported, such as a truck/trailer or a railcar. The test series includes three different basic accident scenarios:

1. Impact test of a truck transport system and nuclear spent fuel shipping cask head-on into a solid concrete barrier.

2: Locomotive grade crossing impact with a truck-tractor trailer system carrying a nuclear spent fuel shipping cask.

3. Impact into a solid concrete barrier and fire test of a special railcar carrying a nuclear spent fuel shipping cask.

These tests provide conditions which have a very low probability of occurring. Statistically, a head-on truck crash into a massive target similar to the one used in the full scale test is so unlikely that a velocity of $96 \mathrm{kph}(60 \mathrm{mph})$ it can be expected to occur no more often than about once in 65 years. If the velocity were increased to $120 \mathrm{kph}(80 \mathrm{mph})$ or more, the predicted frequenry of oscurrence is eomowhat lcss than vilce in every 1, 000 years (the se calculations are based on the assumptions that 3,500-2,000 mile shipments per year are made). In fact, no accidents of such severity involving spent nuclear fuel transport systems have ever occurred. Velocities in all of the tests are in the 96 to $129 \mathrm{kph}(60$ to $80 \mathrm{mph}$ ) range.

The test series has two main purposes: (1) is to assess the validity and utility of analytical and scale modeling techniques for predicting the response of these shipping systems subjected to severe accidents environments, and (2) to gain quantitalive knowledge of the extreme accident environment by measuring the response of representative full scale casks and associated transportation vehicles under actual crash conditions.

These tests are not intended to prove or disprove the validity of the present regulatory standarda. 
This report summarizes the results of the first full scale test in which a $32,000 \mathrm{~kg}(70,000 \mathrm{lb})$ tractor-trailer cask system impacted head-on at $98 \mathrm{kph}(61 \mathrm{mph})$ into a rigid barrier. Analyses completed before the test, including mathematical and scale modeling of the system are described. Results from the full scale test are compared to the pretest analyses.

\section{Analysis}

The basic dynamics and response of the truck-tractor test were investigated by means of a mathematical lumped parameter model. In this type of modeling, the structure is separated into discrete masses and couplings. The coupling definitions are based on analytical estimates of their load-displacement behavior. After the model was formulated, an existing computer program, SHOCK, was used to solve the associated system of equations.

Figure $l$ is a schematic of the lumped parameter model devised for this test. Here the system, including the target, is modeled with eight discrete masses and ten couplings. Mass 1. the target, is fixed and the remaining masses are given initial velocities equal to the impact velocity. Computational results from this model provide estimates of expected deformations as well as displacement-time and velocity-time histories for the components.

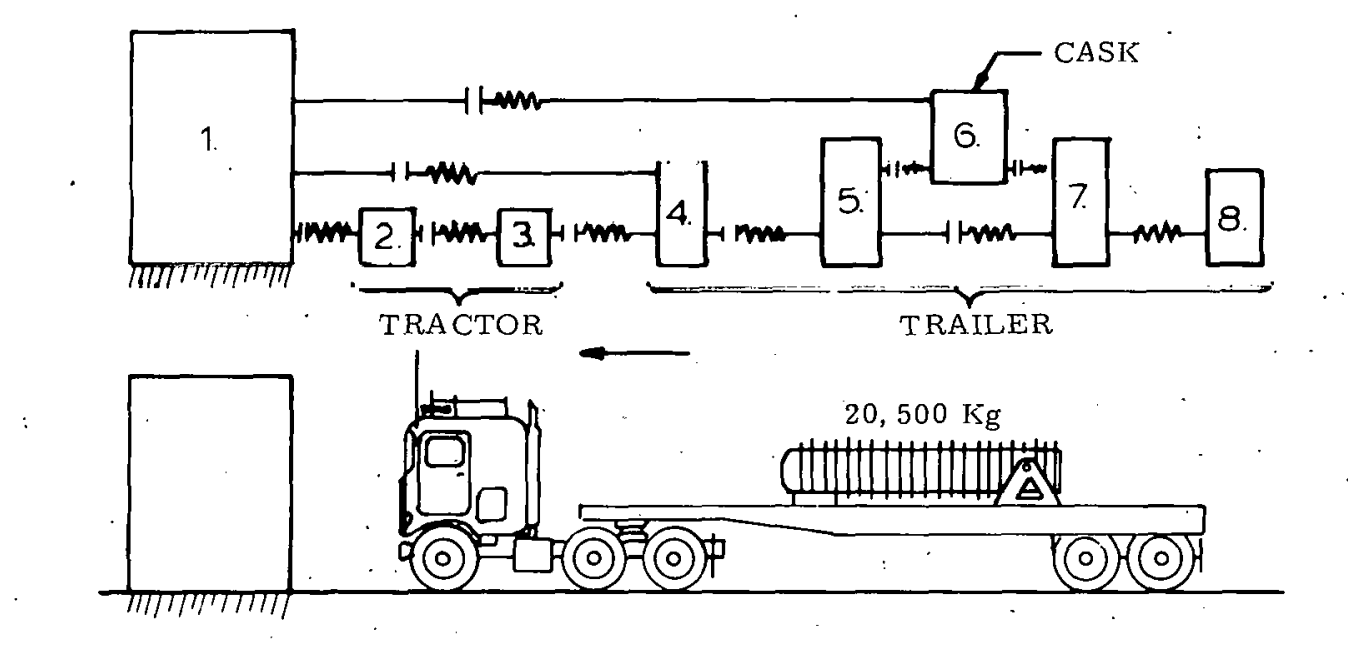

Figure 1. Schematic of the Lumped Parameles. Model

Because of the uncertainties which exist in the used, out-of-service, hardware evaluated in this test (and which to a lesser extent also can exist in new hardware), parameters in the model were varied to obtain information regarding a possible range of system response. In particular, the strength of the container tiedown system was varied. . Results from this parametric study provided definitions of "favorable" and "unfavorable" responses. These can best be depicted by the calculated range of the velocity-time histories illustrated in Figure 2, which were computed with the lumped parameter model. 


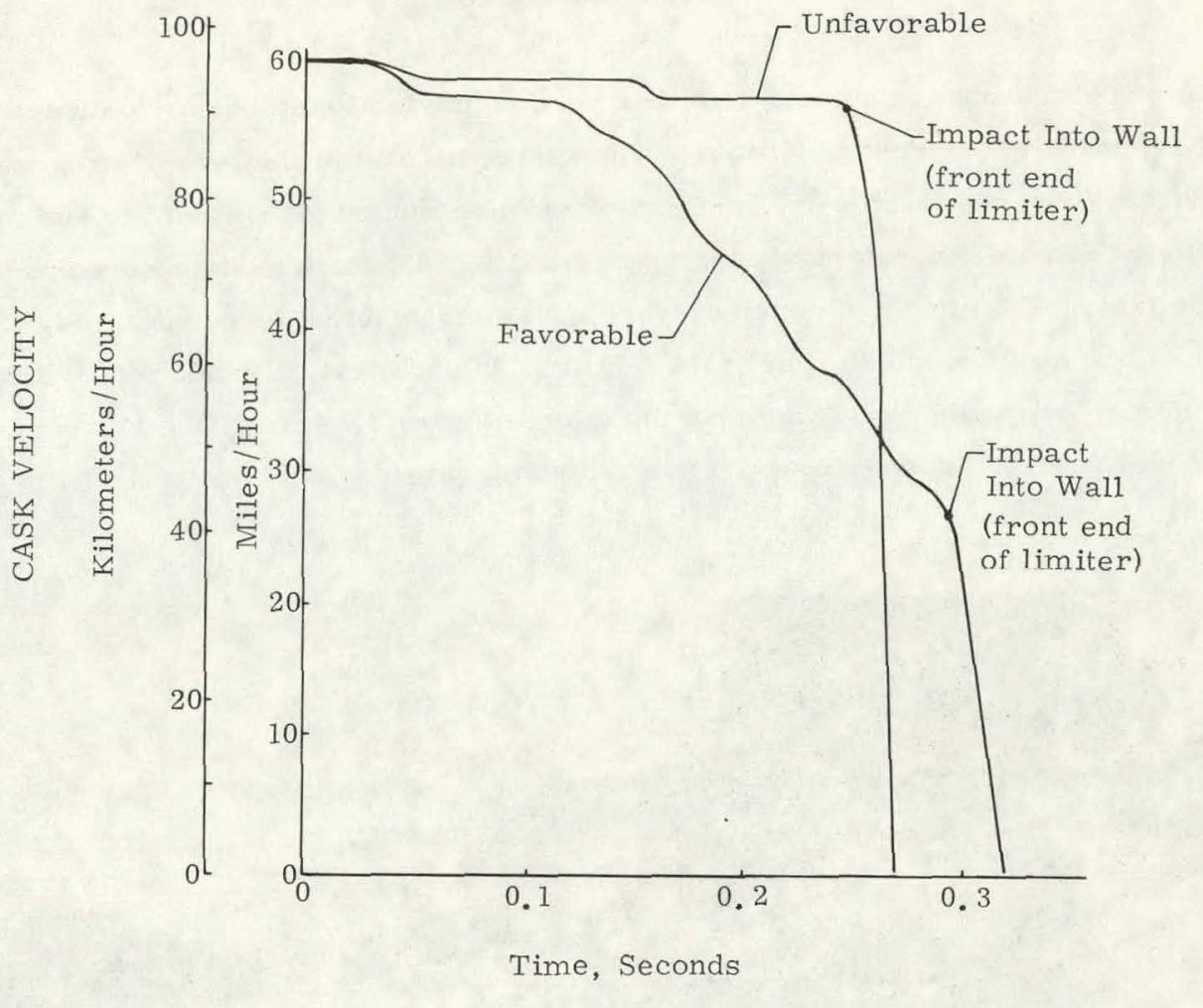

Figure 2. Velocity-Time History for the Container Calculated with the Lump Parameter Model

In the unfavorable case, it was calculated that the container would break free from the trailes slruclure very early in the impact after only a small reduction in velocity and would impact the wall at a relatively high velocity. The resulting velocity change at target impact would be large and rapid. In the favorable case, the container would remain attached to the trailer and would be continuously slowed as the front end of the trailer structure crashed. As a result, it would impact the wall at a much lower velocity (see Figure 2). Detailed dynamic response of the container was invesligated for the worst case, in which the container impacts the wall at the higher velocity.

If the lumped parameter model predicts impacts and forces sufficient to deform the cask, a more detailed finite element computer program, HONDO, is used to obtain information regarding permanent deformations which the cask sustains ${ }^{2}$.

Using reaults from the finile-element model, only very slight deformations to the cask would be expected even for the worst condition (i. e., the unfavorable case). These deformations were not expected to violate the containment capability of the cask. Scale model tests, which are described in more detail in the following section, were performed to verify this analysis. 
Scale model testing can be used to either verify analytical methods or to directly evaluate structural response in accident conditions. Therefore, as part of the overall program, scale model impact tests of the tractor-trailer system were conducted (subsequent to the mathematical modeling) at the Sandia Laboratories' sled track facility. All scale models were constructed with a scale factor of 8 (linear dimensions were $1 / 8$ as large as the prototype). Figure 3 is a photograph of one of the models at the track facility. In each test, a small rocket sled accelerated the model to a velocity slightly higher than the intended impact velocity, the sled was separated from the model, and the model coasted into a scaled target.

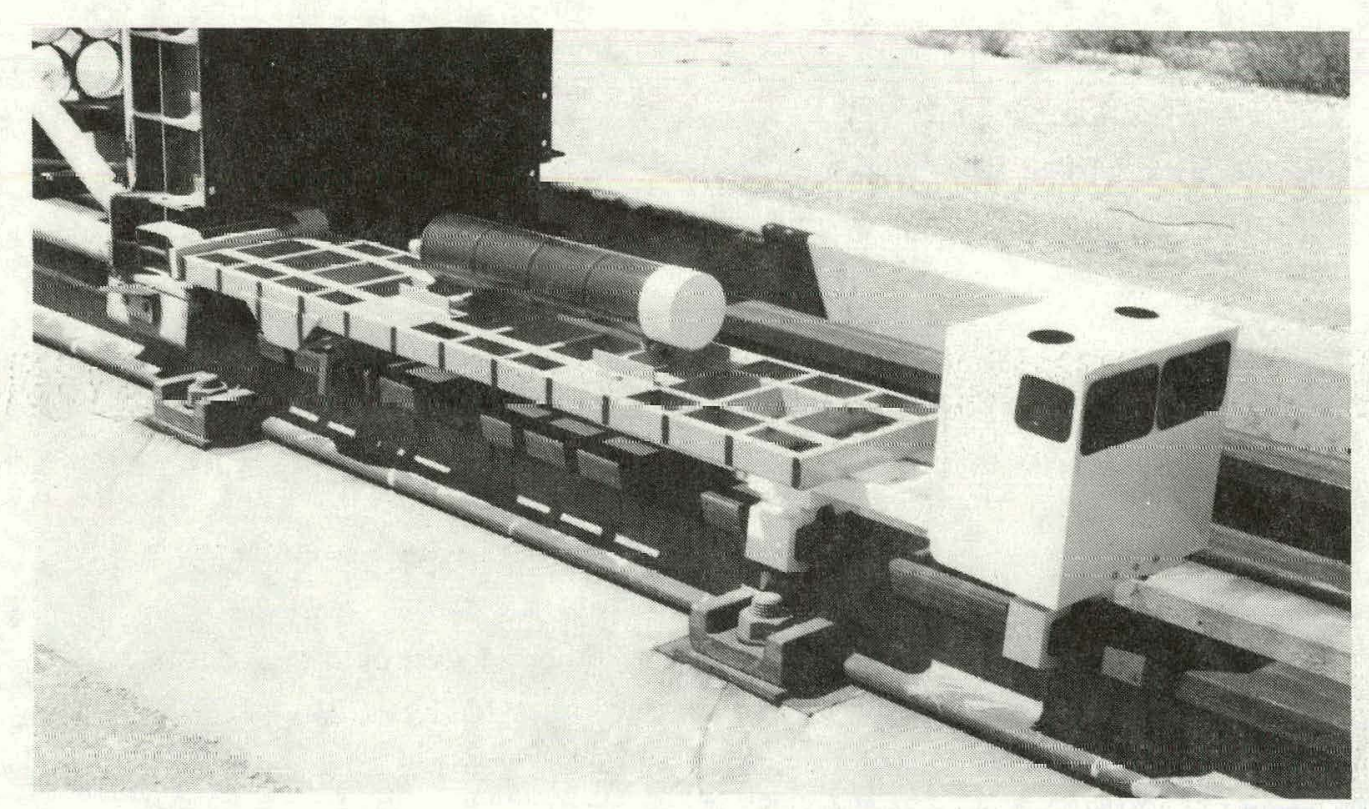

Figure 3. Photograph of the Scale Model at the Track Facility

The scale model system included a tractor, trailer, cask, tiedowns, and impact limiter. Its total weight was $60 \mathrm{~kg}$ (132 pounds). The model cask was a machined stainless steel structure and included lead shielding cast into the annular region between the inner and the outer shells. The cask body, as well as the head and its bolting, were closely scaled approximations of the full scale hardware. An impact limiter, which was incorporated into the full scale test, was included on the model cask. The tractor-trailer model structures were designed with emphasis placed on the major masses and structural elements. Only those elements expected to contribute significantly to the cask dynamics were included. The models, the refore, adequately simulated the major dynamics and resultant damage to be expected in the full scale test. One of the scale model impacts was con ducted at the exact velocity of the full scale test described in this report. Subsequent discussions of scale model results will pertain to this test 
The model test results agreed closely with analytical predictions. In this test, the tractor crushed completely; the front end of the trailer structure separated from the fifth wheel and plowed into the cab, solidly impacting the wall; and a good portion of the front end of the trailer was crushed. The model cask remained nearly horizontal as the vehicular structure crushed; it moved forward through the cab area and impacted the wall in nearly an end-on orientation with the crushed cab in between; the impact limiter was only partially compacted. Figure 4 is a photograph of the model cask and trailer system taken after one of the tests. All of the front end of the trailer deformed and buckled up along the vertical face of the target, the cask suffered negligible damage.

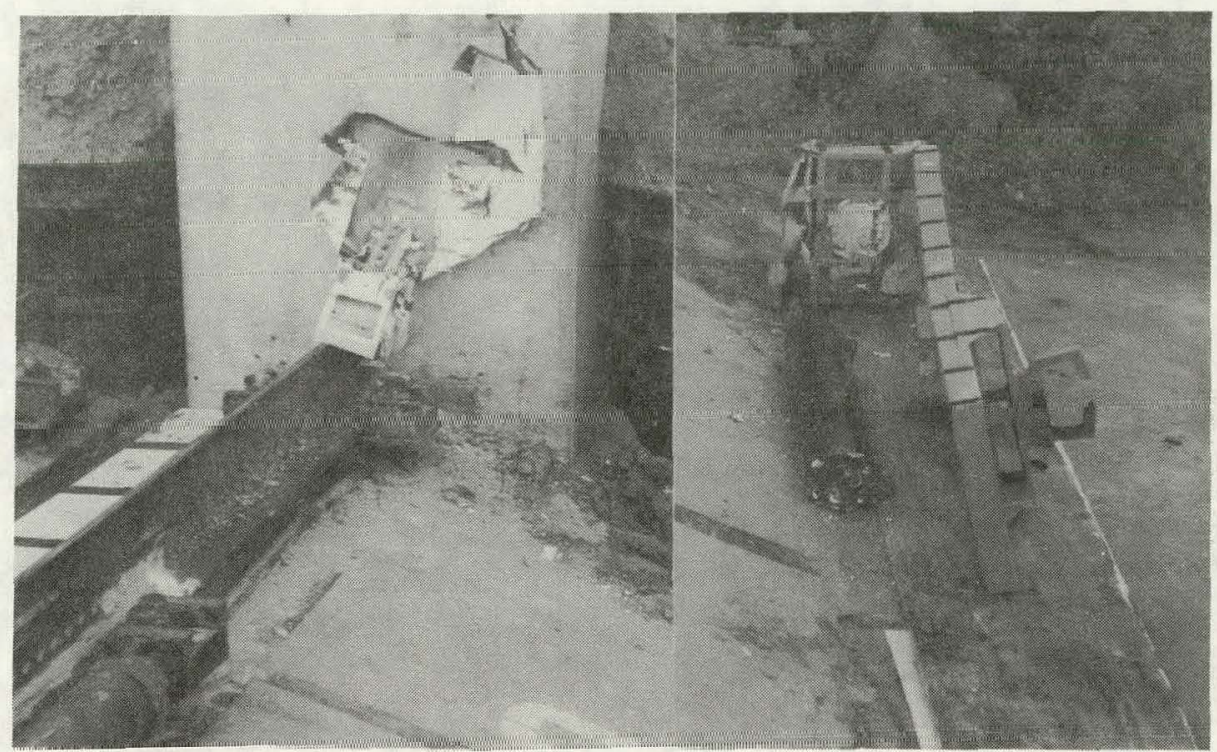

Figure 4. Scale Model after the $98 \mathrm{kph}(61 \mathrm{mph})$ Impact Test

From the scale model test results, it was predicted that: (1) complete destruction of the tractor, and gross deformation to the front end of the trailer would occur in the $96 \mathrm{kph}$ ( $60 \mathrm{mph}$ ) full scale tests; (2) the cask would remain nearly horizontal during crushing of the vehicular structures and would rotate only after impacting the wall; (3) only partial crush of the impact limiter would result; and (4) only minimal damage to external features of the container could bc expected in the first full scale test.

\section{Full Scale Test}

The first tractor-trailer cask test was conducted on January 18, 1977. This test involved a $20,500 \mathrm{~kg}(45,000$ pounds) out-of-service shipping cask mounted head-forward on the same trailer that actually transported it during its time in service. The cask was loaded with a single fresh LWR fuel assembly (PWR) and with $157 \mathrm{~kg}$ (346 pounds) of water as coolant. The trailer 
was coupled to an out-of-service commercial tractor. A rocket-powered sled accelerated the system which was guided by rails. upon separation from the power sled, the system coasted into the target. Extensive photo coverage and onboard instrumentation were provided for the test. Figure 5 is a photograph of the system early in the acceleration phase. Figure 6 is a photograph of the massive and heavily reinforced concrete target, which is comprised of $6.27 \times 10^{5} \mathrm{~kg}(690$ tons) of heavily reinforced concrete backed with $1.58 \times 10^{6} \mathrm{~kg}$ (1740 tons) of earth. The target was designed to be very massive and rigid with respect to the cask impact; that is to say, for all practical purposes considering the masses and velocities involved in the test, the target is essentially unyielding. An object of this size and weight is rarely, if ever, found along normal truck routes.

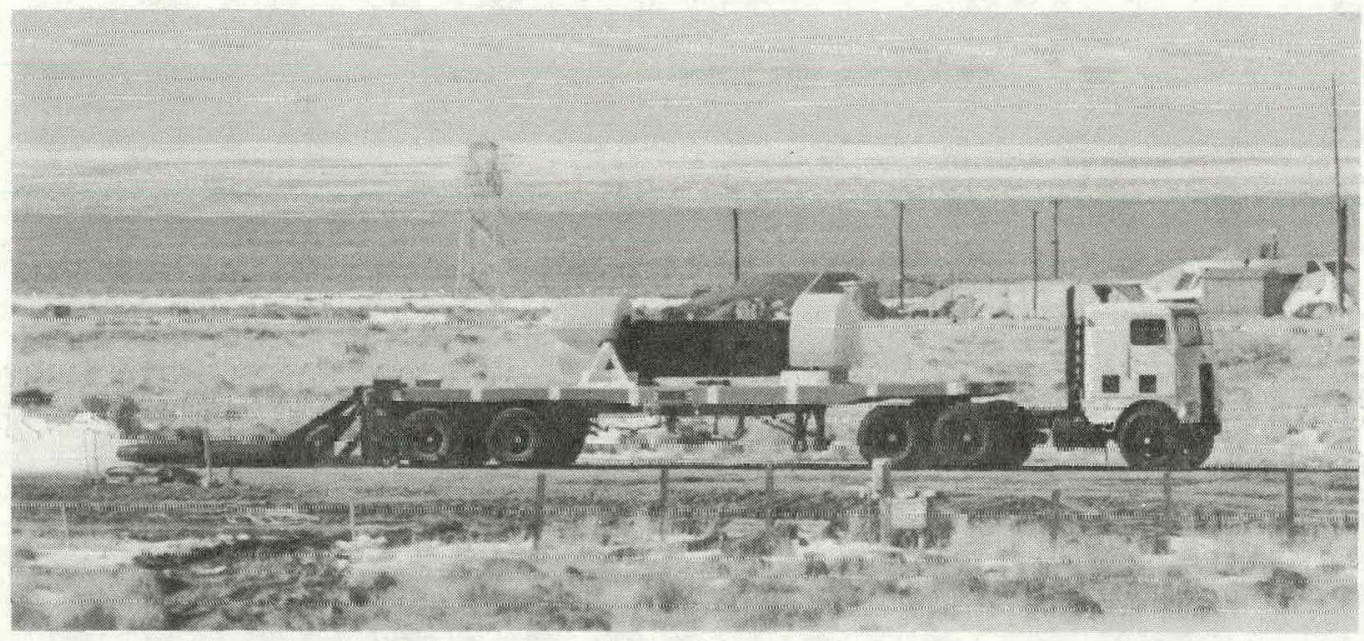

Figure 5. Full Scale System being Accelerated to Impact Velocity

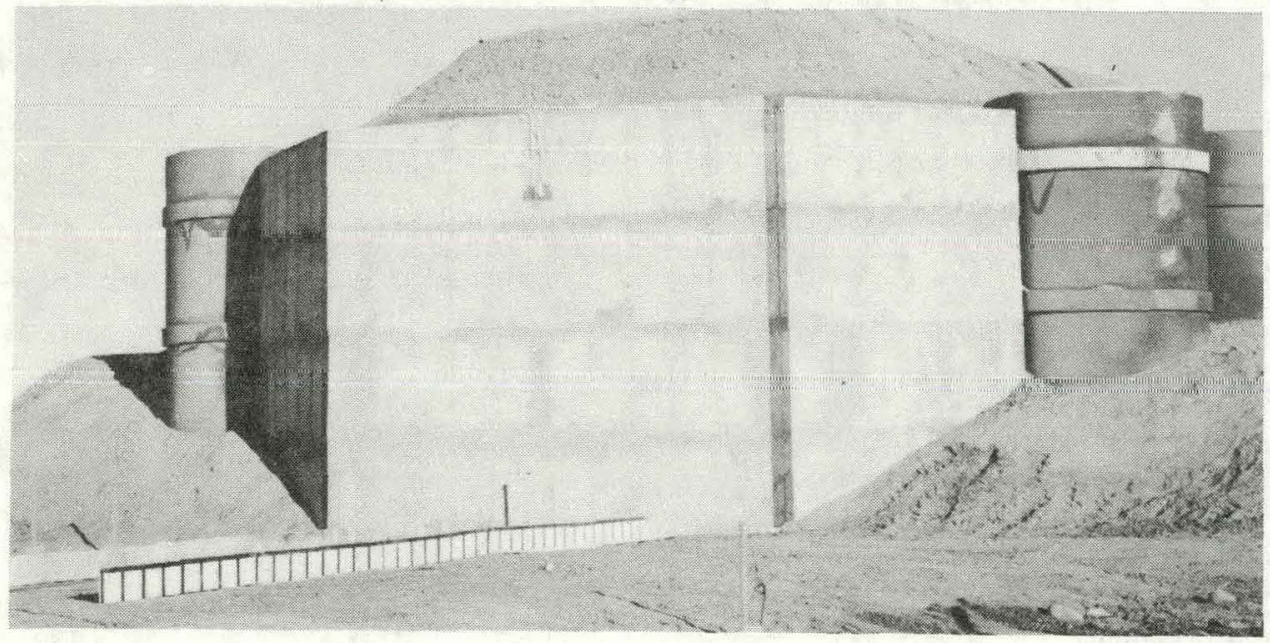

Figure 6. Concrete Target for Full-Scale Test 
The full scale system impacted at $98 \mathrm{kph}(61 \mathrm{mph})$. As both analytical and scale model results predicted, the tractor was completely destroyed in the crash; the trailer moved forward through the cab and impacted the wall; and the front end of the trailer crushed and buckled up along the target face. The cask tiedowns almost broke loose from the trailer frame. The cask remained essentially horizontal during the crush-up of the vehicular structure. It was stopped by the wall, with rubble from the tractor and trailer in between. The cask velocity just as the impact limiter reached the wall was approximately $43 \mathrm{kph}(27 \mathrm{mph})$. The limiter was partially crushed in the axial direction in the final stages of the impact. Following the main impact, the cask and trailer rotated to a maximum angle of approximately 30 degrees relative to horizontal (see Figure 7), and then returned to the roadbed in front of the target. Figure 8, taken immediately after the test, illustrates the condition of the system. The cask remained intact and sustained only minor damage to external cooling fins and piping, and came to rest on the trailer. Instrumentation on the cask body indicated strains were below the yield point of the material. The cask cover was removed without difficulty and the fuel subassembly was found to be intact and undamaged.

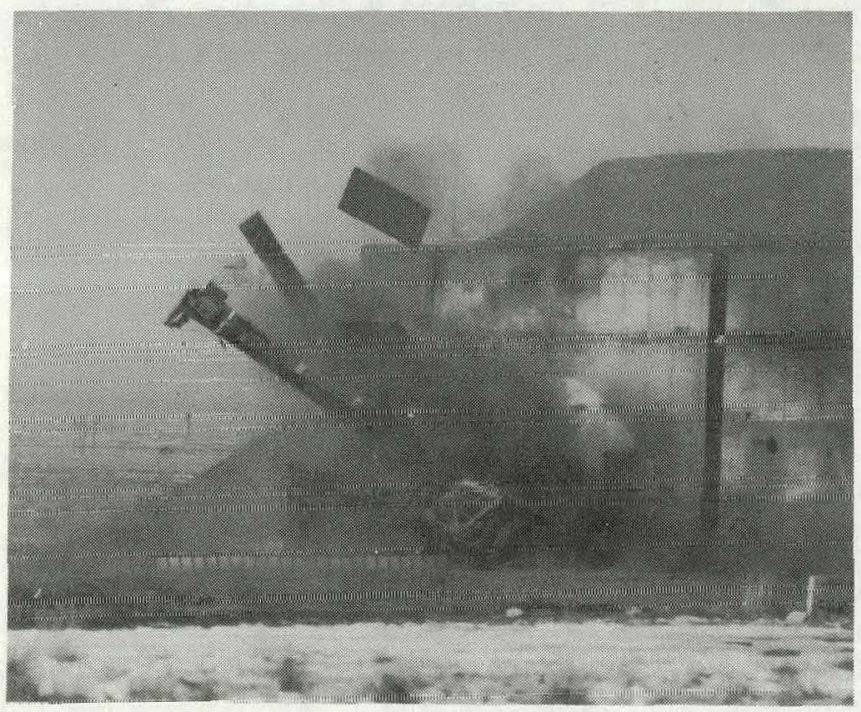

Figure 7. Transport System 1/2 Seconds after Contacting Target 


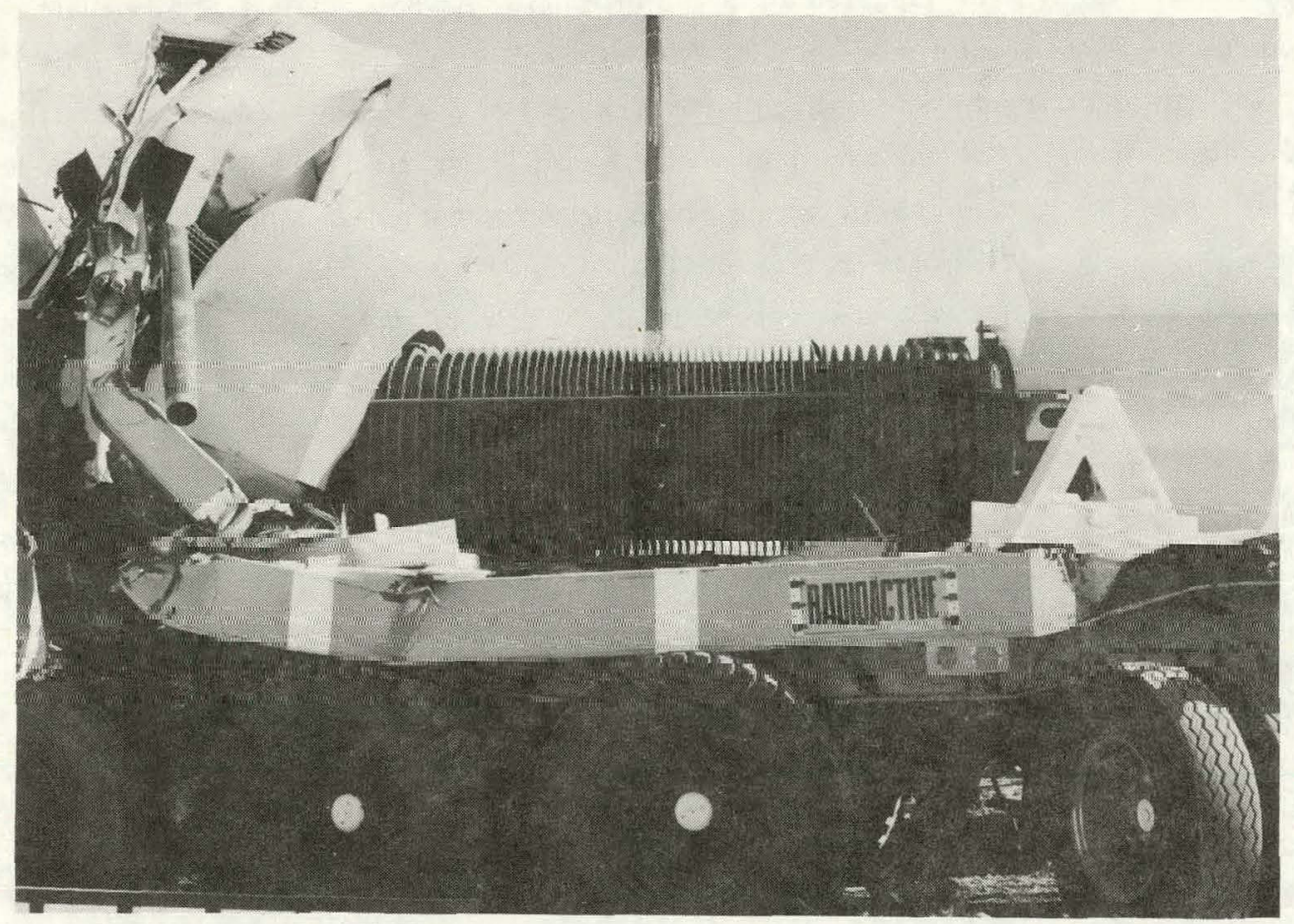

Figure 8. Transport System Subsequent to Impact

\section{Comparison of Analysis to Full Scale Results}

The overall response of the full scale system agreed well with the predictions from analytical and scale model results. For example, the fifth wheel connection between the tractor and trailer failed early in the impact allowing the trailer to move forward crushing the cab. The trailer plowed through the cab solidly hitting the wall and buckling upwards (see Figures 4 and 8 ). The cask rotated only slightly prior to the impact with the target. Partial crush of the impact limiter on the front end of the cask occurred but the cask body was undeformed. These responses were observed in the analysis of the scale model test.

A more quantitative comparison of analysis, scale model, and full scale test results is provided by Figure 9, which illustrates velocity-time histories for the cask from each of these three sources. The full scale results closely paralleled the analytical model predictions using a favorable tiedown response. The scale model velocity-time predictions were also in excellent agreement with full scale test results as can be seen in this figure. Thus, both mathematical analysis and scale model testing generally approximated the container velocity-time history, an important parameter in predicting damage to the shipping container. 


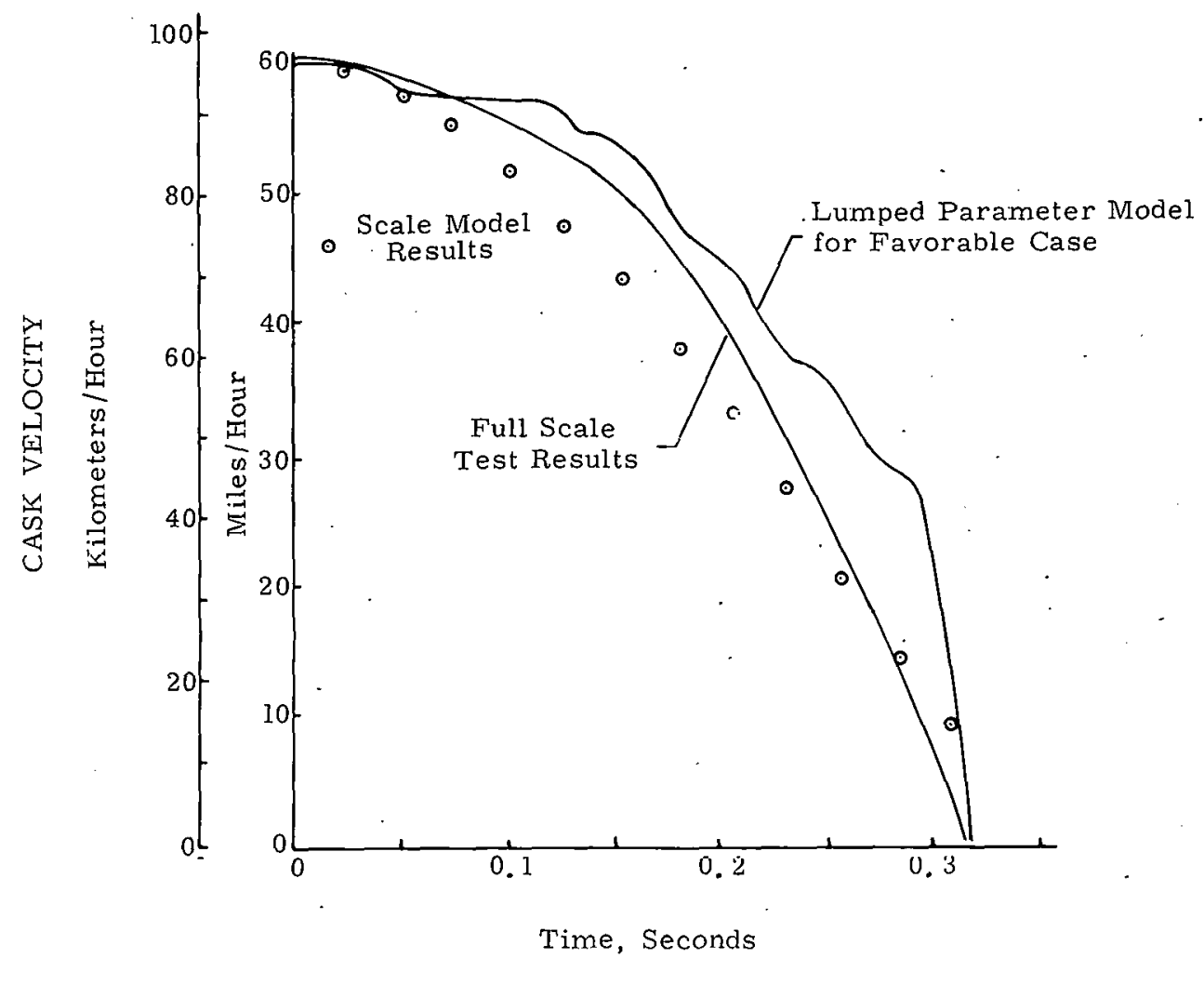

Figure 9. Velocity-Time History for the Cask in the Full Scale Test and from Analysis

Conclusions

The pretest analysis predicted the full scale test results well. The results showed that a lumped parameter model separated into discrete masses and couplings can yield reasonably accurate indications of the behavior of a-system, such as the one tested, even when involved in a violent impact producing gross deformations to peripheral structures. It was demonstrated that a simplified scale model can adequately predict the basic structural behavior in this kind of environment. The scale model response, including times, deformations, and dynamics of the system accurately simulated the behavior of a full scale system.

Although the intent of the full scale vehicle testing program was not to prove or disprove the validity of the present regulatory standards, several observations can be made from the first test. The final impact of the cask into the wall was approximately $43 \mathrm{kph}(27 \mathrm{mph}$ ). This compares to $48 \mathrm{kph}(30 \mathrm{mph})$ in a standard regulatory 9 -meter drop test into an essentially uryielding surface. The reason for this low final velocity is that part of the kinetic energy of the $98 \mathrm{kph}$ full-scale impact test was dissipated in crush-up of the vehicle structure and breaking of the tiedowns. Sufficient energy was absorbed in the structure to reduce the cask velocity to 
less than the impact velocity of the regulatory drop test. Further, additional cushioning was provided by the deformed structure of the tractor and trailer caught between the cask and target while the regulatory drop test requires an essentially unyielding surface. On this basis, it appears that the standards regulatory drop test into an essentially unyielding surface is a more severe standard environment than what the cask was subjected to in this low probability of occurrence full scale test.

\section{References}

1. V. K. Gabrielson and R. T. Reese, SHOCK Code User's Manual, A Computer Code to Solve the Dynamic Response of Lumped-Mass Systems. SCL-DR-69-98, Sandia Laboratories, Livermore, CA 1969.

2. S. W. Keý, HUNUU, A H'inite Élement Computer Program for the Large Deformation Dynamic Kesponse of Axisymmetric Solids, SLA-74-0039, Sandia Laboratories, Albuquerque, NM 1974. 
DISTRIBUTION :

TID-4500-R66 UC-71 (163)

Battelle-Pacific Northwest Laboratory

P.O. Box 999

Richland, WA 99352

Attn: B. Andrews

U.S. Department of Energy

3833 Altez, NE

Albuque rque, NM 87111

Attn: K. Archibeque

Bales Equipment Corporation

P.O. Drawer $Z$

4100 National Parks Highway

Carlsbad, NM 88220

Attn: Wilson Bales, Jr., President

Transportation Safety Institute

Hazardous Materials

6500 South MacArthur Blvd

Oklahoma City, OK 73125

Attn: A. C. Bensmiller, Program Mgr.

Nuclear Assurance Corporation

24 Executive Park West

Atlanta, GA 30329

Attn: R. E. Best, Mgr., Engineèring Services

Yankee Atomic Electric Company

20 Turnpike Road

Route 9

Westboro, MA 01581

Attn: J. M. Bucheit, Engineer

Bureau of Motor Carrier Safety

U.S. Department of Transportation

P. O. Bnx. 9253

Albuquerque, NM 87119

Attn: E. F. Calt, Safety Investigator

Stearns-Roger, Inc.

P.O. Box 5888

Denver, CO 00217

Attn: R. W. Cecil

U.S. Department of Energy

Albuquerque Operations Office

P.O. Box 5400

Albuquerque, NM 87115

Attn: J. N. Cook

W. C. Purchase

Consumers Power Company

1945 Parnall Road

Jackson, MI 49201

Attn: Michale Dickson

Tennessee Valley Authority

630 Commerce Union Bank Building

Chattanooga, TN 37401

Attn: C. Fry, 'Tratfic Branch

Division of Purchassing

Office of Environmental Studies

Research and Test Department

American Railroads Building

1920 L Street NW

W ashington, DC 20036

Attn: C. P. Furber. Manager

Atomic Industrial Forum, Inc.

$7101 \mathrm{~W}$ isconsin Avenue

Washington, DC 20014

Attn: E. Gordon, Nuclear Fuel Cycle, Project Manager

J. S. Glynn, Regional Supervisor

Bureau of Railruad Safety

Department of Transportation

Federal Railroad Aministration

Federal Building, Rm 11A23

519 Taylor Street

Ft. Worth, TX 76102

C. F. Hanley

Nuclear Fuel Transportation Manager

Irradiated Fuel Transport System

Boeing Engineering and Construction

a Division of the Boeing Company

P.O. Box 3707

Seattle, WA 98124

Barnwell Operations

Nuclear Division/NL Industries, Inc.

P.O. Box 928

Barnwell, SC 29812

Attn: A. A. Haskell, Jr., Mgr., Tech. Services

Missouri Pacific Railroad Company

210 North 13th Street

St. Louis, MO 63102

Attn: M. F. Hengel, Mechanical Engineer

Exxun Nuclear Company, Inc.

Fuel Design and Engineering

2101 Horn Rapids Road

Richland, WA 93352

Attn: R. G. Hill, Sr. Engineer

D. B. Henks, Jr.

Asst. to Supt. of Transportation

Atchison, Topeka \& Santa Fe Railway Co.

80 East Jackson Blvd.

Chicago, IL 60604

General Electric Company

Fuel Recovery Operation

Nuslear Energy Division

175 Curtner Avenue

San Jose, CA 95125

Attn: R. H. Jones, Manager

Transportation Systems 


\section{Lovelace ITRI}

Box 5890

Albuquerque, NM 87115

Attn: C. P. J. Kelley

New Mexico Motor Carriers' Assoc., Inc. P.O. Box 25266

Albuquerque, NM 87125

Attn: J. O. Larson, Managing Director

M. Lauriente, P.E.

Office of the Secretary

Office of Systems Engineering

Department of Transportation

400 Tll Slreel, SW

Washingt.nn, Dr. 2.0590

Batelle-Columbus Laboratories

$505 \mathrm{King}$ Avenue

Columbus, OII 43201

Attn: Elmer C. Lusk

Federal Highway Administration

New Mexico Division

17 US Courthouse

Santa Fe, NM 87501

Attn: J. F. MacAllister, Division Engineer

L. Macklin, President

Transnuclear, Inc.

One North Bruadway

White Plains, NY 10601

General Atomic Company

Fort St. Vrain Fuel Project

P.O. Box 81608

San Llego, L:A Y2138

Alls. R. I. Misu:

Exxon Nuclear Company, Inc.

Advanced Storage and Transportation

Project Enginccring

Fuel Reporcessing Department

777-106th Avenue Northeast, C'-00777

Bellevue, WA 98009

Attn: J. H. Nordahl, Manager

I. R. Paschall

Assistant General Attorney Law Dept.

Chesapeake \& Ohio Railway

1700 Terminal Tower

P.O. Box 6419

Cleveland, $\mathrm{OH} 44101$

R. W. Peterson

Director of Transportation

Allied-General Nuclear Services

P.O. Box 847

Barnwell, SC 29812
G. M. Randall, Safety Inspector

Bureau of Railroad Safety

Department of Transportation

Federal Railroad Administration

Room 11-A-23, Federal Building

819 Taylor Street

Fort Worth, TX 76102

Consolidated Edison Company of NY, Inc.

4 Irving Place

New York, NY 10003

Attn: J. A. Pezzello, Sr. Fuel Engineer

The SM Stoller Corporation

3ulle 800, Culuradu Bulding

Rnulder, C. 8030 ?

Attn: M. H. Raudenbush

Union Pacific Railroad

1416 Dodge Street

Omaha, INE 68179

Attn: P. E. Rhine, Engr. of Tests

J. L. Ridihalgh, President

Ridihalgh \& Associates

Nuclear and Thermal

Energy Systems Consultants

2112 Iuka Avenue

Columbus, OH 43201

Western Interstate Nuclear Board

P.O. Box 15038

Lakewood, CO 80215

Attn: W. M. Rogers. Jr.. Director

Oak Ridge National Lab

Y.U. Box $X$

Oak Ridye, TrJ 97090

Attn: D. Seagren

Electric Power Reșearch Institute

3142 II illvicw Avenuc

P.O. Box 10412

Palo Alto, CA 94304

Attn: George Sliter, Project Mgr.

B. R. Teer, Vice President

Transnuclear, Inc.

One North Boradway

White Plains, NY 10601

K. J. Vieg

Directur of Transporlatiun Safety

Illinois Department of Transportation

2300 South Dirksen Parkway

Springfield, IL 62764 .

Westinghouse Electric Corporation

Nuclear Service Division

Power Systems

P.O. Box 2728

Pittsburgh, PA 15230

Attn: H. E. Walchli, Advisory Engineer 
DISTRIBUTION: (cont)

J. W. White, PE

Regional Administrator

U.S. Department of Transportation

Federal Highway Administration

819 Taylor Street

Ft. Worth, TX 76102

I. Yabe, Manager

Nuclear Safety Research Association

Room 1037, National Press Building

Corner 14th and F Street, NW

Washington, DC 20004

Dr. Y. Sousselier

Commissariat a l'Energie Atomique

Commission de Surete des Transports

BP No. 6, F-92260

Fontenay-aux-Roses, Paris, France

Dipl. Ing. Schulz-Forberg

Bundesanstalt fur Materialpruefung (BAM)

Unter den Eichen 87

D-1000 Berlin 45

Federal Republic of Germany

Gerald E. Swindell

International Atomic Energy Agency

Radiological Safety Section

Karntnex Ring 11, P.O. Box 590

A-1011, Vienna, Austria

David G. Walker

Counselor (Atomic Energy)

Australian Embassy

Washington, DC

Dr. John Gaunt

British Imbassy

$3100 \mathrm{M}$ assachusetts Avenue

Washington, DC 20008

Mr. Tetsuo Goto

Nuclear Industry Development

Japan Atomic Industrial Forum, Inc.

No. 1-13, 1-Chome, Shimbashi, Mirialu-ku,

Tokyo, Japan

Stanley Williamson

British Nuclear Fuels Limited

Risley, Warrington WA3 6AS,

Cheshire, England
A. Narath

J. K. Galt

E. H. Beckner

A. W. Snyder

D. J. McCloskey

J. V. Walker

R. M. Jefferson (50)

W. A. Von Riesemann

R. E. Luna

R. B. Pope

G. C. Allen

J. A. Andersen

J. M. Freedman

S. H. Sutherland

H. R. Yoshimura (100)

J. H. Scott

R. S. Claassen

E. A. Aas

C. A. Pepmueller (Actg) (5)

W. L. Garner (3)

For DOE/TIC (Unlimited Release) 